\title{
Great significance of innovative research on capital for building socialist political economics with Chinese characteristics
}

Innovative research on capital

Haiping Qiu

Renmin University of China, Beijing, China

\begin{abstract}
Purpose - General Secretary Xi Jinping pointed out that to uphold and develop socialist political economics with Chinese characteristics, the authors should be guided by Marxist political economics.

Design/methodology/approach - It is an essential methodological principle for building a theoretical system of socialist political economics with Chinese characteristics as a "systematic economic theory".

Findings - To implement this principle, the authors need to understand the rich connotation of Marxist political economics and its relationship with socialist political economics with Chinese characteristics fully and correctly and unswervingly uphold and inherit, creatively transform and innovatively develop the theoretical achievements of Marxist economics, especially capital.

Originality/value - It is also an essential and necessary way to build a theoretical system of socialist political economics with Chinese characteristics.
\end{abstract}

Keywords Marxist economics, Marxist political economics, Capital, Socialist political economics with Chinese characteristics

Paper type Research paper

Since the 18th National Congress of the Communist Party of China (CPC), General Secretary Xi Jinping has put forward an important practical mission "Party committees and governments at all levels should learn and use political economics properly" and a significant concept "socialist political economics with Chinese characteristics". He indicated a major principle that we must adhere to socialist political economics with Chinese characteristics in the comprehensive deepening of economic system reform. He criticised the statement that capital and Marxist political economics are outdated and pointed out that we must adhere to and develop socialist political economics with Chinese characteristics on the methodological principle - "Under the guidance of Marxist political economics, summarising and refining our great practical experience in reform and opening up as well as socialist modernisation while learning from the useful elements of Western economics". Xi proposed the theoretical goal of "upgrading practical experience to systematic economic theory". In the process of building the theoretical

(C) Studies on Marxism. Published in China Political Economy. Published by Emerald Publishing Limited. This article is published under the Creative Commons Attribution (CC BY 4.0) licence. Anyone may reproduce, distribute, translate and create derivative works of this article (for both commercial and noncommercial purposes), subject to full attribution to the original publication and authors. The full terms of this licence may be seen at http://creativecommons.org/licences/by/4.0/legalcode. Originally published in Simplified Chinese in Economic Research Journal.

This paper is the phased result of the major project "Research on the Basic Theoretical Issues of Economics with Chinese Characteristics in the New Era" supported by the National Social Science Foundation of China (Project No. 18VXK002) and the major special project "Research on the Guidance of CPC's Innovation Theory throughout the Knowledge System of Theoretical Economics" of the Ministry of Education (Project No. 19JZDZ002). 
CPE

3,2

system of socialist political economics with Chinese characteristics, how to implement the vital principle of "under the guidance of Marxist political economics" is a theoretical topic worthy of in-depth study. With regard to this topic, the following issues are discussed in this paper.

\section{Comprehensive understanding of the rich connotations of Marxist economics}

To uphold and develop socialist political economics with Chinese characteristics, we must adhere to the guidance of Marxist political economics. Referring to "Marxist political economics", we should understand it comprehensively.

From a broad perspective, it seems not easy to provide a standard definition of "Marxist political economics". In particular, it may be more challenging to determine whether the theories and opinions of economists other than classic Marxist authors fall into Marxist political economics. Lenin pointed out: "Marxism is the system of Marx's views and doctrines." He also stated: "Marx's economic doctrine is the most profound, comprehensive and detailed confirmation and application of his theory" (Central Compilation and Translation Bureau for Works of Marx, Engels, Lenin and Stalin (2009)). Hence, we must first understand Marxist political economics as the political-economic theory of Marxist classic writers, especially Karl Marx himself (and Friedrich Engels), that is, Marx's economic doctrine or Marxist economics. Therefore, "guided by Marxist political economics" refers first to "guided by Marxist economics".

The next question is what contents Marxist economics include. Capital is a well-known classic work on Marxist political economics, and Marxist political economics that people usually talk about refers first to the theories contained in capital. However, it should be pointed out that the theories in capital should not be deemed as the entire contents of Marxist economics. In fact, from a broader perspective, Marxist economics contains a wealth of content in other aspects besides the theories in capital.

Karl Marx once formulated a "six-volume plan" for his critique of political economy, which consists of capital, Landed Property, Wage-Labour, The State, Foreign Trade and World Market. Capital was gradually evolved based on the "General Formula for Capital" chapter in the capital volume written by Marx. Although academia has different opinions on whether Marx replaced the "six-volume structure" with the later Capital structure, it is certain that Marx made many discussions in a series of documents on the relevant contents of the last chapters of capital and the last five of six volumes. In the 1990s, Chinese Marxist economists conducted a systematic study on this issue, ended by Zibenlun xupian tansuo (Exploration of Continuation of Capital) compiled and published by Professor Tang (1999).. This critical research achievement showed that, in addition to capital, Marx had made extensive expositions on competition, credit, share capital, landed property, wage-labour, the state, foreign trade and world market, which constituted an extremely important part of Marxist economics. Undoubtedly, understanding and studying these theories and ideological contents of Marx will not only help us understand Marxist economics more comprehensively but also facilitate the development of Marxist political economics, which is conducive to building a theoretical system of socialist political economics with Chinese characteristics [1].

Moreover, in Marxist classics such as The Communist Manifesto, Capital, The Critique of the Gotha Programme and Anti-Dühring, Marx and Engels summarised and described the basic economic characteristics of future socialist and communist society, mainly including the public/social ownership of the means of production, planned production, distribution according to work, distribution according to needs, harmony between human and nature, free and all-round development of human beings, etc. There is no doubt that Marx and Engels' theories concerning the fundamental economic characteristics of the future society are an integral part of Marxist economics. In fact, this part of Marxist economics theories and thoughts had a profound impact on the later theory and practice of socialist political 
economics. It is still of practical guiding significance in principle and direction for building the theory and system of socialist political economics with Chinese characteristics in the new era. Some people categorically deny the great practical significance of Marx and Engels' scientific socialism theory on the ground that socialism with Chinese characteristics differs in many aspects from Marx and Engels' vision of the future society, which is entirely wrong. Meanwhile, the practice has proved that it is also wrong to treat Marx and Engels' theoretical assumptions about the future society dogmatically or equate these theoretical assumptions and the actual socialist development path directly.

We should also see that Marx not only studied the problems of proletarian revolution and the transition to communism in developed capitalist countries but also conducted serious studies on the problems of backward countries and nations in leaping over the "Caudine Forks" and formed a wealth of ideas on the transition of backward countries and nations to communism. These ideas are also essential contents of Marxist economics. Although these thoughts of Marx are based on the premise that the proletariat in developed countries will take the lead in winning the proletarian revolution, there is no doubt that these thoughts of Marx have a more direct practical guiding significance for our understanding of the development path and laws of socialism with Chinese characteristics (Qiu, 1997).

In addition, Marx also discussed extensively on various pre-capitalist social economies, which fell into the ideological content of "general political economics" [2]. These ideological contents constitute an extremely valuable part of Marxian economics and are also critical ideological resources of socialist political economics with Chinese characteristics.

In brief, Marxist economics contains very rich theoretical contents, which are all sources of crucial theories and philosophies concerning socialist political economics with Chinese characteristics. In principle, we should inherit and use them properly. However, from the normalisation of categories, the accuracy of theories, the rigour of logic, the integrity of systems and other aspects, capital is the essence of Marxist economics and also the encyclopaedia of Marxist political economics. In the aspect of theories, it has a vital and irreplaceable position. Hence, we should first study how to uphold and inherit, creatively transform and innovatively develop the theoretical achievements of capital.

\section{Adherence to and inheritance, creative transformation and innovative development of the theoretical achievements of capital}

General Secretary Xi Jinping pointed out: "Adherence to the guidance of Marxism is the fundamental sign that distinguishes contemporary Chinese philosophy and social sciences from other philosophy and social sciences, and must be upheld firmly with a clear-cut stand" (Xi, 2016). As mentioned above, "the guidance of Marxist political economics" first refers to the guidance of Marxist economics. To be more exact, it refers first to adherence to and inheritance, creative transformation and innovative development of the theoretical achievements of capital. Then, what are the scientific connotations and specific methods for adherence to and inheritance, creative transformation and innovative development of the theoretical achievements of capita?

Certainly, adherence to and inheritance, creative transformation and innovative development of the theoretical achievements of capital refer first to thorough implementation of the worldview and methodology embodied in capital, namely, dialectical materialism and historical materialism. General Secretary Xi Jinping indicated that: "Marxist principles concerning the materiality of the world, the human society, the nature of cognition and their laws of development have provided us with basic worldview and methodology for studying and mastering various disciplines and fields of philosophy and social sciences" (Xi, 2016). It is known that Marx turned to the study of political economics after he established historical materialism. In the "Preface", A Contribution to the Critique of Political Economy, Marx gave a classic description of the basic principles of historical materialism and pointed out that it was 
$\mathrm{CPE}$

3,2

332

the "general result" that guided his research on political economics (Karl, 2009a). In the Postscript to Capital, Vol. 1 (2nd German Edition), Marx clearly stated that the method (methodology) he used was materialistic dialectics (Karl, 2009b). In the Preface to Capital, Vol. 1 (French Edition), Marx pointed out: "The method of analysis that I employed had not previously been applied to economic subjects. .." (Karl, 2009c). It was precise because Marx applied materialistic dialectics and historical materialism to the analysis of economic issues that he surpassed the classical political economics in Britain and France and realised the revolution of political economics. Needless to say, materialistic dialectics and historical materialism are the general and universal scientific worldview and methodology that guide the study of all social issues. As Marxist political economics with Chinese characteristics, socialist political economics with Chinese characteristics should, of course, implement the worldview and methodology of materialistic dialectics and historical materialism.

On the other hand, we should realise that it is far from enough to understand the guiding position and role of theoretical achievements of capital for socialist political economics with Chinese characteristics from the methodological perspective alone. In fact, in capital, methodologies were integrated with theories, and they should not be understood separately. Deviating from the theoretical content of capital and emphasising the guiding position and role of Marx's economic methodology alone and one-sidedly is tantamount to replacing Marxist economics with Marxist philosophy, which is unscientific and incorrect [3]. Moreover, in fact, capital is a complete system composed of research objects, basic stand, research objectives, research methods, a series of categories and principles, narrative methods (i.e. logic) and other theoretical achievements. Hence, to uphold the guidance of Marxist economics, in addition to upholding the worldview and methodology of dialectical and historical materialism embodied in capital, we should also treat the relationship of research objects, basic stand, research objectives, basic categories, basic theories, logical methods and other theoretical achievements of Capital with socialist political economics with Chinese characteristics scientifically. We believe that adherence to and inheritance, creative transformation and innovative development of theoretical achievements of capital in all aspects are not only the complete connotation and specific methods guided by Marxist economics but also a critical approach to building a theoretical system of socialist political economics with Chinese characteristics, which is exactly the issue that we need to study deeply and is the direction of our efforts.

From the perspective of scientific development laws, adherence and inheritance, creative transformation and innovative development of the outstanding scientific and cultural heritage of mankind are not only the basic requirements of the general laws for scientific progress but also reflect the inherent demand of socialist political economics with Chinese characteristics and the essential connection between socialist political economics with Chinese characteristics and Marxist economics. General Secretary Xi Jinping pointed out that, to build a system of philosophy and social sciences with Chinese characteristics, we should fully leverage the resources in three areas, namely, Marxist resources, excellent Chinese traditional culture and foreign philosophy as well as social science resources. There is no doubt that these three resources have different positions and functions in building socialist political economics with Chinese characteristics, which should not be confused. The reason is that socialist political economics with Chinese characteristics is a theoretical reflection of the economic practice of socialism with Chinese characteristics, and the economic practice of socialism with Chinese characteristics is fundamentally a process that the CPC consciously integrates the basic principles of Marxism with China's reality. During this process, the CPC appropriately absorb and beneficially use excellent Chinese traditional culture and outstanding foreign philosophy and social science achievements for reference. Hence, to build a theoretical system of socialist political economics with Chinese characteristics, we shall still adhere to the correct theoretical principles and directions, focus on studying how to uphold and inherit, creatively transform and innovatively develop the theoretical achievements of capital in all aspects. 
3. Specific ways to apply the theoretical achievements of capital scientifically

We advocate the construction of a theoretical system of socialist political economics with Chinese characteristics through adherence to and inheritance, creative transformation and innovative development of the theoretical achievements of capital. First, a basic principle should be determined; that is, creative transformation and innovative development must be implemented on the premise of adherence and inheritance, with the ultimate goal of better adherence and development. Then, what are the precise meaning of adherence and inheritance, creative transformation and innovative development of the theoretical achievements of capital? Due to space limitations, only some preliminary discussions are conducted herein.
Innovative research on capital

\subsection{Adherence to and inheritance of critical theoretical elements of capital}

To be guided by Marxist economics, in addition to upholding and carrying forward the worldview and methodology of dialectical and historical materialism, we should also adhere to and inherit many theoretical elements of capital that are of great significance to the socialist political economics with Chinese characteristics, which are shown as below.

First, the basic stand and values in Capital. General Secretary Xi Jinping pointed out: "Adhere to the guidance of Marxism, focussing on answering the question of 'for whom'. The question of 'for whom' is a fundamental principle issue in philosophy and social science studies. For whom the philosophy and social sciences scholars write books and establish theories, whether to serve the minority or the vast majority, is a question that must be clarified" (Xi, 2016). Different from bourgeois ideology, Marxism publicly recognises its proletarian stand and values. The development history of Marxist thought suggests that Marx established lofty worldview and life values early in his youth, laying a solid ideological foundation for his becoming a great thinker later. However, Marx was not born a proletarian thinker and revolutionist. It was after an in-depth study of social history and reality did Marx discover the law of class struggle and the historical status of the working class; it was after he established the scientific theory of historical materialism did he take a stand for the working class and the working people more consciously. For Marx, the discovery of scientific theories had a decisive effect on the determination of his class stand and sense of value. The scientist and revolutionist sides of Karl Marx were dialectically unified.

Undoubtedly, socialist political economics with Chinese characteristics originates from the practice of socialist economic construction with Chinese characteristics under the leadership of the CPC. The people-centred philosophy is the original aspiration and the consistent class stand and values of the $\mathrm{CPC}$. Hence, socialist political economics with Chinese characteristics must consciously adhere to and inherit the class stand and values embodied in capital and insist on the organic unity of scientificity and class stand, which determines that socialist political economics with Chinese characteristics can only be economics that serves people rather than capital. Certainly, due to the presence of various capitals in the socialist economic practice with Chinese characteristics, a new theory concerning capital should be established for socialist political economics with Chinese characteristics for realising the ultimate goal of serving the people and meeting the practical needs of capital use.

Second, the general principles of social production and market economy in capital. As the capitalist economy is objectively manifested as the organic unity of social production process, commodity production (market economy) and the capitalist mode of production, capital theoretically proposed the general principles of social production and market economy, besides focussing on revealing the unique laws of economic movement in the capitalist society. For example: in different links of social production, exchange, distribution, consumption, etc., production is always the decisive link, while other links have a certain counter-effect on production. Human labour and all natural resources represented by land in a broad sense are the original sources of social wealth. Land is the mother of wealth, and labour 
CPE

3,2

334

is the father of wealth and an active element. Labour productivity is determined by a variety of circumstances, including the average proficiency of workers, the level of scientific development and the degree of application of science in technology, the social integration in the production processes, the scale and efficiency of the means of production and natural conditions. Only by allocating the total social labour to different productions in proportion can the various needs of people be met. All savings are ultimately savings of time, which is the "primary law". The basis of all developed divisions of labour with commodity exchange as an intermediary is the separation of urban and rural areas. The entire economic history of society can be summed up in this oppositional movement. Commodities have both use-value and value. Use-value is the basis and premise of value, and value is ordinary human labour condensed in commodities determined by the social labour time required for its production. The value of a unit commodity is inversely proportional to the social labour productivity of producing the commodity. Exchange value or price is the manifestation of value and is also affected by the relationship between supply and demand. The price fluctuates around value, which is the realisation form of the law of value. With the continuous development of commodity and value forms, currencies eventually came into being. In essence, the currency is a commodity that is produced from commodity exchange and serves as a universal equivalent. The essence of currency is not only manifested but also covered up by the currency's functions, such as value scale, circulation means, payment means, storage means, and world currency. The amount of currency in circulation is determined by the amount of commodity value to be realised in circulation. The circulation of paper currency shall observe the law of currency circulation; otherwise, inflation will occur. On the one hand, the law of value drives the increase in social labour productivity. On the other hand, it can cause the differentiation of producers and even the bankruptcy of some producers, laying a foundation for establishing the capitalist mode of production under certain social conditions.

Undoubtedly, in terms of fundamental characteristics, the socialist economy with Chinese characteristics is an organic unity of social production, market economy and socialist mode of production. To build a theoretical system of socialist political economics with Chinese characteristics requires adherence to and inheritance of the aforementioned general principles of capital, which is generally a consensus in the political economics community with little controversy.

Third, capital is the basic theory on the laws of capitalist economic movement. It profoundly reveals the laws of economic movement in capitalist society and scientifically demonstrates the historical limitations of the capitalist mode of production and capitalism. It indicates a historical trend that the capitalist mode of production will inevitably be replaced by a superior social mode of production (communist mode of production), laying a solid theoretical foundation for the proletarian revolution and socialist construction. The practice of socialism with Chinese characteristics has been carried out under the guidance of the core theories in capital and the whole Marxist theory. Only by adhering to and carrying forward the core theories in capital can the socialist political economics with Chinese characteristics be theoretically legit and rational. Doubts or even denial of the core theories and scientific conclusions in capital may render the invalidity of the concept of "socialist political economics with Chinese characteristics", let alone building a theoretical system of socialist political economics with Chinese characteristics. It is also generally a consensus of the political economics community without controversy in principle. In short, only by adhering to and developing the aforementioned significant theoretical elements of capital can we ensure that the socialist political economics with Chinese characteristics is Marxist political economics with Chinese characteristics, instead of economics with any other nature.

3.2 Creative transformation of categories and expositions in capital

Also, adhering to the guidance of Marxist economics requires creative transformation of certain categories and basic principles in Capital for analysing the socialist economy with 
Chinese characteristics and meeting the theoretical needs of building a theoretical system of political economics with Chinese characteristics. The categories and basic principles herein mainly refer to the core categories and theories in capital, such as capital, labour commodity and surplus-value.

Since categories and theories such as capital, labour commodity and surplus-value were categories and theories created by Marx to describe capitalist economic relations, whether they can be used in socialist political economics has been a controversial topic in academia for a long time. However, with the development of socialist economic practices with Chinese characteristics, some critical changes can be seen. For example, the category of "capital" has been widely applied in academia, and the concept of "state-owned capital" has been used in government documents for a long time. Regarding the question of how to treat the applicability of the two core categories ("labour commodity" and "surplus-value") to the socialist market economy, the mainstream view in academia remains that labour commodity and surplus-value can be used directly to analyse China's private or non-state-owned economy but not the socialist public economy [4]. Based on this understanding, academia has conducted long-term explorations on how to create the corresponding new concepts and proposed some different concepts and categories, which, however, have not been widely recognised. In fact, from a theoretical logic perspective since the assets in the public economy can be expressed by "capital", why cannot the categories of "labour commodity" and "surplus-value" that are closely related to "capital" apply? Previously, the main concern of people was that as the above categories reflected capitalist economic relations, if these categories and theories were directly applied to the analysis of the socialist economy, it would "obliterate the essential difference between socialism and capitalism" and "create huge ideological confusion". It now appears that this issue needs to be reconsidered.

From the perspective of scientific development history, the creation of new concepts is the manifestation and result of scientific progress. Redefining existing concepts or categories is also an essential manifestation of scientific progress. They are both "revolution of the terminology". For example, in ancient Western philosophy, "atom" represented the basic unit of the world, which was only an abstract philosophical category. With the development of natural sciences, people's understanding of "atom" has continuously deepened, endowing this term with different levels of connotation. In chemistry and classical physics, "atom" refers to the smallest unit in a chemical reaction and a structure composed of atomic nuclei and electrons, respectively. With the development of elementary particle physics, people's understanding of "atom" is further deepening. Nevertheless, the concept of "atoms" is still used and has not been abandoned due to the development of science. The same phenomenon exists in the development of economics. For example, classical economists proposed a series of terms and concepts such as use-value, exchange-value, value, wage, fixed capital and circulating capital. However, people's understandings of these terms and concepts and their relationships are often unscientific. Marx carried forward these terms and concepts and endowed them with new connotations, making them the categories of scientific and political economics.

Hence, the inheritance and re-definition of existing academic terminology is an important way and method to achieve scientific development. Regarding "labour commodity" and "surplus-value", despite their specific meanings in Capital to reflect specific production relations of pure capitalism, we can still redefine these terms while inheriting them, that is, implementing creative transformation to make them into new categories.

From the actual economic development of China, with the establishment and development of the socialist market economic system, there is legitimacy for free movement of labour and the labour market even in the state-owned economy from the institutional level. However, since the labourers in the state-owned economy legally have the public ownership of the means of production, they cannot be considered as those in the purely capitalist mode of 
CPE

3,2

336

production, i.e. purely sellers of labour-power. After such explanations, to reflect the free movement of labour and the transactional characteristics of the market, the term "labour commodity" can be used for analysing the value of labour-power in the public economy and its realisation. However, in the context of socialist political economics with Chinese characteristics, it only indicates that the labour force has free mobility and tradability, not that the labourer is a dispossessed person who has lost the ownership of the means of production.

This creative transformation method is also applicable to the term "surplus-value". In capital, "surplus-value" refers explicitly to capitalists' possession or exploitation of the part of the value created by wage-labourers with surplus labour time, which is a special social form of surplus labour, namely, capitalist form. Surplus labour is a common phenomenon after human productivity is developed to a certain level and stage, and without surplus labour, there would be no development of human civilisation. However, surplus labour is a historical category. In different historical stages, necessary labour and surplus labour have different connotations and division characteristics. Simply speaking, the labour of labourers can also be divided into necessary labour and surplus labour in pre-capitalist societies. The characteristic of this division is that necessary labour does not refer to the labour through which labourers reproduce the value of their labour-power as a commodity, but the part of labour that belongs to labourers and is determined by slave owners or feudal landlords through super-economic coercion. This part of labour and its products or value allows labourers and their families to get simple reproduction and expanded (or enlarged) reproduction occasionally, but it may often lead to reduced reproduction, which precisely reflects the cruelty of class exploitation in slavery and feudal societies. Under capitalist conditions, the necessary labour of workers is not determined by super-economic coercion. Instead, as labour has become a commodity, the market mechanism turns out to be a vital factor affecting the realisation of labour commodity value and determining necessary labour. As a result, in most cases, the necessary labour of workers is predetermined by the value of their labour-power as a commodity, and then the surplus labour of workers forms the surplus-value possessed by capitalists, which is an essential manifestation of the historical rationality of the capitalist production mode. Certainly, it does not exclude the phenomena that capitalists take various coercive approaches and manipulations to obtain a sufficient amount of surplus-value, thereby infringing on workers' necessary labour and making their wages lower than the value of labour-power, as analysed by Marx in Capital.

In the socialist public economy, there is undoubtedly a distinction between necessary and surplus labour. However, under the conditions of a socialist market economy, not only necessary labour and surplus labour have new connotations but their division mechanism also has new features. Specifically, the necessary labour here is affected by the value of labour-power and also the distribution system according to work. It is reasonable to call it necessary labour just to distinguish it from surplus labour. Meanwhile, surplus labour in the public economy and the value it creates fundamentally belong to labourers. In this sense, it also has the nature of necessary labour. However, from the perspective of primary distribution, it still falls into the category of surplus labour. Accordingly, it is also valid to call the value created by labourers' surplus labour as surplus-value. The surplus-value here no longer reflects the exploitation of workers by private capitalists but the primary distribution relationship of socialism and the economic relationship among public enterprises, the state and workers.

In brief, we should be guided by the methodology of historical materialism, deeply understand the historical significance of economic categories, endow the terms and concepts in capital with new connotations through inheritance and the creative transformation and propose new basic principles based on these terms and concepts to analyse the real economic movement of socialism with Chinese characteristics and build the theoretical system of socialist political economics with Chinese characteristics. 
3.3 Innovative development of the objective and object of research on capital

Furthermore, to adhere to the guidance of Marxist economics, we should innovatively develop relevant theoretical achievements of capital based on adherence to and inheritance of critical theoretical elements of capital. Here we take the objective and object of research on capital as examples only.

As mentioned earlier, the class stand and values of capital and the socialist political economics with Chinese characteristics are consistent. Hence, their research objectives are essentially serving the proletariat and working people. We should also recognise the critical difference in theoretical tasks between Capital and the socialist political economics with Chinese characteristics.

Marx clearly pointed out in the preface to Volume I of Capital: "The ultimate aim of this work is to lay bare the economic law of motion of modern society." The scientificity and class nature of Marxian economics are unified. Hence, the fundamental purpose of capital is to provide scientific theoretical basis and guidance of political economics for the proletarian revolution. Then, what are the fundamental tasks facing socialist political economics with Chinese characteristics, or say, what is the objective of research on socialist political economics with Chinese characteristics?

Social existence determines social awareness. From the relationship between theory and practice, on the one side, socialist political economics with Chinese characteristics is derived from the economic practice of socialism with Chinese characteristics and is the theoretical product of this practice; on the other side, it undertakes the critical mission of providing a theoretical basis and guidance for the economic practice of socialism with Chinese characteristics. The socialist political economics with Chinese characteristics and capital have a relationship of inheritance and development in terms of research objectives and theoretical tasks. Specifically, like capital, socialist political economics with Chinese characteristics must first reveal the laws of social and economic movements of socialism with Chinese characteristics and then provide theoretical support and policy service for the economic practice of socialism with Chinese characteristics on this basis. Hence, socialist political economics with Chinese characteristics and capital are entirely consistent in terms of research objectives and theoretical tasks. However, there are also certain differences, reflecting a relationship of inheritance and development between them.

We should also see that capital took British capitalism as a "typical example" and regarded it as a mature capitalist economic system theoretically, revealing the general laws of capitalist economic movement. In contrast, the investigation object of socialist political economics with Chinese characteristics is the economic movement in the primary stage of socialism in our country, rather than the mature or developed socialist economic system. As objectively, some laws of the socialist economic movement may not be fully manifested in the primary stage of socialism, we cannot require the socialist political economics with Chinese characteristics to be precisely like capital, revealing the laws of economics only. However, it must be developed innovatively based on revealing the laws, that is, it is necessary to analyse the contradictions and problems in the economic practice of socialism with Chinese characteristics based on revealing the laws of socialist economics and propose constructive countermeasures for further reform and development. Only by combining the three aspects: revealing laws, analysing contradictions and problems and making constructive propositions, can the socialist political economics with Chinese characteristics reflect the organic unity of science, reality and constructiveness, thereby better serving the practice of socialist economic construction with Chinese characteristics.

The research object should also be innovatively developed. Marx expressly pointed out in the preface to Volume I of Capital: "In this work, I have to examine the capitalist mode of production, and the conditions of production and exchange corresponding to that mode." According to the research object, three major theoretical volumes of Capital examined the
Innovative research on capital 
$\mathrm{CPE}$

3,2

338

production process of capital, the circulation process of capital and the overall process of capitalist production (i.e. the unified process of production, circulation, and distribution), respectively. Hence, the research object of capital established by Marx stipulated the theoretical contents and their logical relationship. To build a theoretical system of socialist political economics with Chinese characteristics, we need to determine the research object accurately at first.

An important feature of the "Socialist political economics with Chinese Characteristics" is clearly defining the research object as the "Socialist Economy with Chinese Characteristics" and revealing the general laws of the socialist economic movement by investigating and analysing the process of the socialist economic movement with Chinese characteristics. It is the inheritance and development of the Marxist political economics research method, that is, revealing the general economic laws of certain social forms through the investigation and research of economic movements in specific countries.

Since the research objective (theoretical task) of socialist political economics with Chinese characteristics has three levels, it is necessary to have a relatively comprehensive understanding of the research objects of socialist political economics with Chinese characteristics. Specifically, the research objects of socialist political economics with Chinese characteristics are as follows: first, the socialist mode of production with Chinese characteristics and its corresponding production and exchange relations; second, the operation of socialist economy and its contradictions; third, the economic development and reform issues. Only in this way can the socialist political economics with Chinese characteristics reflect the organic unity of scientificity (revelation of laws), practicality (analysis of economic operations) and constructiveness (proposal of reforms and development policies). It is an important feature and innovative representation of socialist political economics with Chinese characteristics as well as an essential methodological principle and development direction for building the theoretical system of socialist political economics with Chinese characteristics.

\section{Summary}

This paper discusses how to build a theoretical system of political economics with Chinese characteristics under the guidance of Marxist political economics in a theoretical way from several aspects. First, the paper theoretically summarises the connotations of Marxist political economics and the rich contents of Marxist economics and points out the special position of capital in Marxist economics, providing a starting point for further exploring the concrete ways of upholding the guidance of Marxist economics. Then, the paper concretely transforms "upholding the guidance of Marxist economics" into three levels of approaches and methods, which are adherence and inheritance, creative transformation and innovative development and preliminarily discusses their applicability to socialist political economics with Chinese characteristics with the combination of the theoretical achievements of capital, including methodology, research objectives and objects, general theories concerning social production and market economy, some categories and principles and assumptions about future society. The primary purpose of this paper is to show that adherence to and inheritance, creative transformation and innovative development of the theoretical achievements of capital are an essential and necessary way to build a theoretical system of socialist political economics with Chinese characteristics. Due to space limitations, topics such as the logical mainline and methods of capital have yet to be duly discussed. Some critical theoretical issues involved in the paper still require further study.

\section{Notes}

1. In fact, Chinese political economists have conducted a lot of study on Marx's six-volume plan and made a wealth of academic achievements. 
2. For example, The Origin of the Family, Private Property and the State by Engels is a classic in this aspect.

3. Hence, we do not completely agree with Lukács' options below: "Orthodoxy refers exclusively to method in the problems of Marxism.” Refer to Lukács, G. (1996), History and Class Consciousness (Chinese edition), The Commercial Press, Beijing, 1996, p. 48.

4. In recent years, in some academic achievements of Chinese political economics, scholars have directly used the categories of "surplus-value" and "surplus-value rate" to analyse China's economy without special explanations. Strictly speaking, it is not rigorous or scientific, and we disagree.

Innovative research on capital

\section{References}

Central Compilation and Translation Bureau for Works of Marx, Engels, Lenin and Stalin (2009), Liening Zhuanti Wenii: Lun Makesi Zhuyi [Lenin Monographs: On Marxism], People's Publishing House, Beijing, pp. 7-17.

Karl, M. (2009a), "A contribution to the critique of political economy", Central Compilation and Translation Bureau for Works of Marx, Engels, Lenin and Stalin (Trans.), Marx \& Engels Collected Works, People's Publishing House, Beijing, Vol. 2, p. 591.

Karl, M. (2009b), "The postscript to capital, Vol. 1 (2nd German edition)", Central Compilation and Translation Bureau for Works of Marx, Engels, Lenin and Stalin (Trans.), Marx \& Engels Collected Works, People's Publishing House, Beijing, Vol. 5, pp. 20-22.

Karl, M. (2009c), "The postscript to capital, Vol. 1 (French Edition)", Central Compilation and Translation Bureau for Works of Marx, Engels, Lenin and Stalin (Trans.), Marx \& Engels Collected Works, People's Publishing House, Beijing, Vol. 5, pp. 20-22.

Qiu, H.P. (1997), "Makexi Engesi guanyu bufada guojia Xiang gongchanzhuyi guodu de lilun ji qi xianshi yiyi" [Marx and Engels' theory on the transition of underdeveloped countries to communism and its practical significance], Dangdai jingji yanjiu [Contemporary Economic Research], Vol. 8 No. 1, pp. 30-37.

Tang, Z.X. (1999), Zibenlun Xupian Tansuo [Exploration of Continuation of Capital], China Financial Publishing House, Beijing.

Xi, J. (2016), "Speech at the Symposium on the work of philosophy and social sciences", People's Daily, available at: http://www.xinhuanet.com/politics/2016-05/18/c_1118891128.htm (accessed 15 August 2020).

\section{Further reading}

Bai, Y.X. (2005), "Chongxin renshi shehui zhuyi shichang jingji zhong de ziben yu shengyu jiazhi”, [Re-understand Capital and Surplus Value in Socialist Market Economy], Guangdong shangxueyuan xuebao [Journal of Guangdong University of Business Studies], Vol. 20 No. 4, pp. 4-8.

Gu, H.L. (2019), Zhongguo Tese Shehui Zhuyi Zhengzhi Jingiixue Shigang [Outline History of Socialist Political Economics with Chinese Characteristics], Higher Education Press, Beijing.

Liu, M.Y. (2018), "Makesi jingjixue tixi dui gouzhu Zhongguo tese shehui zhuyi zhengzhi jingjixue de zhidao yiyi", [Guiding significance of Marxist economic system for the construction of socialist political economics with Chinese characteristics], Dangdai jingji yanjiu [Contemporary Economic Research], Vol. 29 No. 3, pp. 22-30.

Song, T. (1995), "Ziben he shengyujiazhi bushi zibenzhuyi jingji he shehuizhuyi jingji de tongyong fanchou" [Capital and surplus-value are not general categories of the capitalist and socialist economy], Gaoxiao lilun zhanxian [Theoretical Front in Higher Education], Vol. 8 No. 7, pp. 19-22. 
$\mathrm{CPE}$ 3,2
Wang, C.K. (2017), "Zhongguo tese shehui zhuiyi zhengzhi jingjixue-luoji, fanchou, lilun" [Socialist political economics with Chinese characteristics: logic, category and theory], Shehui kexue jikan [Social Science Journal], Vol. 39 No. 4, pp. 5-10.

Yan, P.F. (2018), "Xinshidai Zhongguo tese shehuizhuyi zhengzhi jingjixue yanjiu duixiang he luoji qidian" [Research object and logical starting point of socialist political economics with Chinese characteristics in the new era], Neimenggu shehui kexue [Inner Mongolia Social Sciences] (Chinese Edition), Vol. 39 No. 4, pp. 27-31.

Zhang, Y. (2016), Socialist Political Economics with Chinese Characteristics, China Renmin University Press, Beijing.

\section{About the author}

Haiping Qiu: (1962-), Professor at the School of Economics, Renmin University of China, "Zicai" Chair Professor at the School of Economics, Peking University (Beijing 100872). Haiping Qiu can be contacted at: haipingqiu@sohu.com

For instructions on how to order reprints of this article, please visit our website: 